\title{
Correction: QTC prolongation in acute medical admissions: an often overlooked and potentially serious finding
}

Coughlan JJ, Wafer M, Fitzgerald G, et al. QTc prolongation in acute medical admissions: an often overlooked and potentially serious finding. Postgrad Med J 2018;94:123-24.

The author Gearoid Fitzgerald's name should be spelt as Gerald Fitzgerald.

(c) Article author(s) (or their employer(s) unless otherwise stated in the text of the article) 2018. All rights reserved. No commercial use is permitted unless otherwise expressly granted.

Postgrad Med J 2018;94:243. doi:10.1136/postgradmedj-2017-135208.corr1

D) Check for updates 